\title{
Biocompatibility and Osteogenic Potential of Calcium Silicate-Based Cement Combined with Enamel Matrix Derivative: Effects on Human Bone Marrow-Derived Stem Cells
}

\author{
Hye-Min Kim ${ }^{1}$, Donghee Lee ${ }^{2}$ and Sin-Young Kim ${ }^{1, *(D)}$ \\ 1 Department of Conservative Dentistry, Seoul St. Mary's Hospital, College of Medicine, The Catholic \\ University of Korea, 222 Banpo-daero, Seoul 06591, Korea; hmtoto@naver.com \\ 2 College of Medicine, The Catholic University of Korea, Seoul 06591, Korea; dong524@naver.com \\ * Correspondence: jeui99@catholic.ac.kr
}

Citation: Kim, H.-M.; Lee, D.; Kim, S.-Y. Biocompatibility and Osteogenic Potential of Calcium Silicate-Based Cement Combined with Enamel Matrix Derivative: Effects on Human Bone Marrow-Derived Stem Cells. Materials 2021, 14, 7750.

https://doi.org/10.3390/ma14247750

Academic Editor: Arne Berner

Received: 13 November 2021 Accepted: 13 December 2021 Published: 15 December 2021

Publisher's Note: MDPI stays neutral with regard to jurisdictional claims in published maps and institutional affiliations.

Copyright: (c) 2021 by the authors. Licensee MDPI, Basel, Switzerland. This article is an open access article distributed under the terms and conditions of the Creative Commons Attribution (CC BY) license (https:/ / creativecommons.org/licenses/by/ $4.0 /)$.

\begin{abstract}
The characteristics of retrograde filling material are important factors that can affect the long-term success of apical microsurgery. Various calcium silicate-based cements (CSC) were introduced to overcome drawbacks of mineral trioxide aggregate (MTA), while Emdogain is known to be effective in the regeneration of periodontal tissues. The aim of this study is to evaluate the biocompatibility and osteogenic potential of various CSCs combined with Emdogain on human bone marrow-derived mesenchymal stem cells. Experimental groups were classified into eight groups depending on the material and the presence of Emdogain. In the cell-counting kit test, all experimental groups combined with Emdogain showed higher cell viability compared with those without Emdogain at days 1 and 2. In the wound-healing assay, cell migration increased significantly over time, with or without Emdogain. In the alkaline phosphatase assay, all groups treated with Emdogain showed higher activity compared with those without Emdogain at day $3(p<0.05)$. Using alizarin red S staining, all groups treated with Emdogain showed greater calcium nodule formation compared with those without Emdogain at days 7 and $14(p<0.05)$. In conclusion, using CSCs as retrograde filling materials and the application of additional Emdogain will increase bone regeneration and improve the prognosis of apical microsurgery.
\end{abstract}

Keywords: calcium silicate-based cement; Emdogain; mineral trioxide aggregate; human bone marrow-derived mesenchymal stem cell; biocompatibility; osteogenic potential

\section{Introduction}

Tight apical sealing affects the success of apical microsurgery, and the regeneration of peripheral bone destroyed by apical inflammation is an important indicator of success [1-3]. Mineral trioxide aggregate (MTA) has excellent features, such as biocompatibility, odontoblastic ability, and tight sealing properties [4]. One of the representative retrograde filling materials, ProRoot MTA (Dentsply Tulsa Dental Specialties, Tulsa, OK, USA), induces the migration and proliferation of human bone marrow-derived mesenchymal stem cells (hBMSCs) [5]. Although it is known to be effective in the regeneration of periapical destructed bone, it has the disadvantages of discoloration, heavy metal content, and a long setting time [6-10]. Recently, various types of MTA and calcium silicate-based cements (CSCs) have been introduced and commercialized for effective sealing of root ends during apical microsurgery [4,11-14].

CSCs have been developed with the advantage of reduced setting time and no discoloration. They can be hardened in bleeding conditions and therefore applied more easily during retrograde filling procedures in apical microsurgery [15-18]. In particular, RetroMTA (BioMTA, Seoul, Korea) has been reported to be biocompatible and have adequate physical properties in comparison with ProRootMTA [19,20]. Endocem MTA Premixed (Maruchi, Wonju, Korea) is a recently developed material with a pre-mixed 
CSC included in a syringe, making it easier for the practitioner to apply it [21]. Enamel matrix derivative (EMD) is mostly composed of amelogenin and is known to contain growth factors. It has demonstrated significant potential in the regeneration of periodontal defects when applied to the root surface during periodontal surgery [22-25]. There are many recent reports regarding the use of Emdogain Gel (Straumann, Basel, Switzerland) in endodontics [26-30].

The aim of this study is to compare the biocompatibility and osteogenic potential of ProRoot MTA, RetroMTA, and Endocem MTA Premixed combined with Emdogain Gel on human bone marrow-derived stem cells (hBMSCs).

\section{Materials and Methods}

\subsection{Human Bone Marrow-Derived Stem Cells (hBMSCs)}

This study was approved by the Institutional Review Board of Seoul St. Mary's Hospital, the Catholic University of Korea (IRB No. MC20SESI0067). Human mesenchymal stem cells derived from bone marrow (Catholic MASTER Cells) were procured from the Catholic Institute of Cell Therapy (CIC, Seoul, Korea). The cell line was anonymously established at the $\mathrm{CIC}$, and second-generation Catholic Master Cells were used in this study. The cells were cultured in growth medium, which was made up of Hyclone $10 \%$ bovine serum (GE Healthcare Life Sciences), $100 \mathrm{U} / \mathrm{mL}$ of penicillin, and $100 \mu \mathrm{g} / \mathrm{mL}$ of streptomycin ( $\alpha$-MEM; GE Healthcare Life Sciences, Pittsburgh, PA, USA). Cell cultures were maintained in a humid environment at $37^{\circ} \mathrm{C}$ with $5 \% \mathrm{CO}_{2}$. In a colony-forming test, most hBMSCs maintained a fusiform morphology, which is constant with other kinds of mesenchymal stem cells. All experiments were accomplished under sterile state.

\subsection{Production of Retrograde Filling Materials Disks}

The retrograde filling materials evaluated in this study were ProRoot MTA, RetroMTA, Endocem MTA Premixed, and Emdogain Gel. Their composition is listed in Table 1. Each cement was mixed according to its manufacturer's instructions. We made disk-shaped specimens with a diameter of $6 \mathrm{~mm}$ and a height of $3 \mathrm{~mm}$ for each cement, using a sterile rubber mold. All discs were sterilized for $4 \mathrm{~h}$ using ultraviolet rays on a clean bench after setting, covered with wet gauze at room temperature for $72 \mathrm{~h}$.

Table 1. Materials used in this study, their manufacturers, and chemical compositions.

\begin{tabular}{|c|c|c|c|}
\hline Material & Manufacturer & Composition & Batch Number \\
\hline ProRoot MTA & $\begin{array}{c}\text { Dentsply Tulsa Dental } \\
\text { Specialties, Tulsa, OK, USA }\end{array}$ & $\begin{array}{l}\text { Portland cement (tricalcium } \\
\text { silicate, dicalcium silicate, and } \\
\text { tricalcium aluminate) } 75 \% \\
\text { Calcium sulfate dihydrate } \\
\text { (gypsum) } 5 \% \\
\text { Bismuth oxide } 20 \%\end{array}$ & 0000186484 \\
\hline RetroMTA & BioMTA, Seoul, Korea & $\begin{array}{l}\text { Calcium carbonate } 60-80 \% \\
\text { Silicon dioxide } 5-15 \% \\
\text { Aluminum oxide } 5-10 \% \\
\text { Calcium zirconia complex } \\
\text { 20-30\% }\end{array}$ & RM1810D14 \\
\hline $\begin{array}{l}\text { Endocem MTA } \\
\text { Premixed }\end{array}$ & Maruchi, Wonju, Korea & $\begin{array}{l}\text { Natural pure cement } \\
\text { Bismuth trioxide }\end{array}$ & C2304160716 \\
\hline Emdogain Gel & $\begin{array}{l}\text { Straumann, Basel, } \\
\text { Switzerland }\end{array}$ & $\begin{array}{l}\text { Amelogenin } 90 \% \\
\text { The remainder is proline-rich } \\
\text { nonamelogenin, tuftelins, tuft } \\
\text { proteins, ameloblastin, and } \\
\text { amelins }\end{array}$ & ISO 15223-1 \\
\hline
\end{tabular}

\subsection{Classification of the Groups}

The experimental groups in this study were constituted as follows:

Group 1 (ProRoot MTA): The ProRoot MTA disks were made using the method described above. Growth medium (GM) was used to monitor cell viability and cell migration, 
and osteogenic medium (OM) was used in alkaline phosphatase (ALP) analysis and alizarin red $S$ (ARS) staining assay to observe cell differentiation.

Group 2 (ProRoot MTA combined with Emdogain Gel): Emdogain was added to the $\mathrm{GM}$ or OM at a concentration of $100 \mu \mathrm{g} / \mathrm{mL}$, and the experimental process was the same as for group 1.

Group 3 (RetroMTA): the experiment was conducted using RetroMTA disks in the same way as for group 1.

Group 4 (RetroMTA combined with Emdogain Gel): Emdogain was added to the medium at a concentration of $100 \mu \mathrm{g} / \mathrm{mL}$, and the experimental process was the same as for group 3 .

Group 5 (Endocem MTA Premixed): the experiment was conducted using Endocem MTA Premixed disks in the same way as for group 1.

Group 6 (Endocem MTA Premixed combined with Emdogain Gel): Emdogain was added to the medium at a concentration of $100 \mu \mathrm{g} / \mathrm{mL}$, and the experimental process was the same as that used for group 5.

Group 7 (Control): the control group included hDPSCs cultured without experimental disks.

Group 8 (Emdogain Gel): Emdogain was added to the medium at a concentration of $100 \mu \mathrm{g} / \mathrm{mL}$, and the experimental process was the same as that used for group 7. The Emdogain group included hDPSCs cultured with the above medium without experimental disks.

\subsection{Cell Viability Measurement}

A Cell Counting Kit test (CCK-8) (CK04-13; Dojindo, Kumamoto, Japan) was used to evaluate the cytotoxic effects of the three kinds of experimental disks. The cell proliferation rate of hBMSCs was analyzed shortly after incubation, and analyzed again 1,2, and 4 days after incubation. hBMSCs were cultured at a density of $1.0 \times 10^{4}$ cells/well in 24-well cell culture plates (SPL Life Sciences, Pocheon, Korea) in growth medium. After $24 \mathrm{~h}$ of incubation of the adherent cells, the optical density value was obtained.

Individual disks were placed on an insert (SPLInsert; SPL Life Sciences) with pores $0.4 \mathrm{~mm}$ in size, while the inserts were located above the hBMSCs. Each well was supplemented with $1 \mathrm{~mL}$ of additional medium in order to cover the top of the disk. hBMSCs cultured without experimental disks were used as a control group. Emdogain at the initial concentration of $30 \mathrm{mg} / \mathrm{mL}$ was added to groups $2,4,6$, and 8 , and diluted in $\alpha$-MEM for experimental use at a final concentration of $100 \mu \mathrm{g} / \mathrm{mL}$. A total of $20 \mu \mathrm{L}$ CCK-8 solution was added to each well, and the plates were placed in an incubator at $37^{\circ} \mathrm{C}$ for $1 \mathrm{~h}$. Later, we rinsed each well with PBS, and added dimethyl sulfoxide for dissolving the synthesized formazam. Absorption at $450 \mathrm{~nm}$ was measured using an absorbance microplate reader (Power Wave XS; BioTek Instruments, Winoski, VT, USA). Each group was measured in octuplicate.

\subsection{Cell Migration Assay}

A wound-healing assay was used to evaluate cell migration ability. The hBMSCs were sprayed at a density of $3.5 \times 10^{4}$ cells/well in growth medium in a 24-well plate. After $24 \mathrm{~h}$ of incubation, a 1000- $\mu \mathrm{L}$ pipette tip was used to create scratches in the middle of each adherent cell layer. After scratching, the detached cell debris was washed away with PBS. After an additional $24 \mathrm{~h}$ of incubation, each individual disk was placed on an insert in a well. Emdogain at the initial concentration of $30 \mathrm{mg} / \mathrm{mL}$ was added to groups 2, 4, 6, and 8 , diluted in $\alpha$-MEM to a final concentration of $100 \mu \mathrm{g} / \mathrm{mL}$. hBMSCs were incubated for 4 days with the experimental disks, with the medium replaced every $48 \mathrm{~h}$. Images of cell migration were collected at $0,1,2$, and 4 days using a phase-contrast microscope (Olympus, Tokyo, Japan). We used ImageJ 1.46r software (National Institutes of Health, Bethesda, MD, USA) for measuring the surface area covered by cells. The degree of cell migration from both sides to the scratched region was calculated based on the area of initial scratched region. Each group was measured in quadruplicate. 


\subsection{Alkaline Phosphatase (ALP) Activity}

The osteogenic potential of hBMSCs was evaluated on days 3 and 6, using an ALP assay. The hBMSCs were sprayed at a density of $3.5 \times 10^{4}$ cells/well in a 24 -well cell culture plate and then cultured in osteogenic medium. The osteogenic medium was made up of complete $\alpha$-MEM, $50 \mu \mathrm{g} / \mathrm{mL}$ ascorbic acid (Sigma-Aldrich, St. Louis, MO, USA), $0.1 \mu \mathrm{M}$ dexamethasone (Sigma-Aldrich), and $10 \mathrm{mM}$ beta-glycerophosphate (SigmaAldrich). Individual disks were placed on inserts in the wells. Emdogain at an initial concentration of $30 \mathrm{mg} / \mathrm{mL}$ was added to groups $2,4,6$, and 8 , and diluted in osteogenic medium to a final concentration of $100 \mu \mathrm{g} / \mathrm{mL}$. hBMSCs with experimental disks were incubated for 6 days, with the medium replaced every $48 \mathrm{~h}$. At each observation point, ALP activity was evaluated using Senso-Lyte ${ }^{\circledR}$ p-nitrophenylphosphate (pNPP) alkaline phosphatase assay kit (AnaSpec, Fremont, CA, USA) by the manufacturer's method. Finally, an absorbance microplate reader was used to measure the optical density at $405 \mathrm{~nm}$. Each group was measured in sextuplicate.

\subsection{Alizarin Red S (ARS) Staining Assay}

The ARS staining assay was used to evaluate the formation of calcium nodules in hBMSCs. Each experimental disk was incubated in osteogenic medium and kept in an incubator at $37^{\circ} \mathrm{C}$ and $100 \%$ humidity for 7 days, producing a concentration of $5 \mathrm{mg} / \mathrm{mL}$ experimental eluate for each tested material. The superficial fluid was purified by $0.20-\mu \mathrm{m}$ filters (Minisart; Sartorius Stadium Biotech, Göttingen, Germany). hBMSCs were sprayed at a density of $2.0 \times 10^{4}$ cells/well in a 24-well cell culture plate, then incubated for 14 days in the experimental material eluates. Emdogain at an initial concentration of $30 \mathrm{mg} / \mathrm{mL}$ was added to groups $2,4,6$, and 8 , and diluted in osteogenic medium to a final concentration of $100 \mu \mathrm{g} / \mathrm{mL}$. The cells were fixed with a $4 \%$ paraformaldehyde and a $2 \%$ ARS solution (ScienCell, Carlsbad, CA, USA) for $20 \mathrm{~min}$. The staining was performed for $15 \mathrm{~min}$ with 10\% cetylpyridinium chromide (Sigma-Aldrich). Finally, an absorbance microplate reader was used to measure the optical density at $560 \mathrm{~nm}$. Each group was measured in sextuplicate.

\subsection{Statistical Analysis}

The SPSS software program (ver. 24.0; IBM Corp., Armonk, NY, USA) was used for statistical analysis. Shapiro-Wilk normality verification was used to evaluate the distribution of the data. After confirming the normality of the data, a repeated-measures analysis of variance (RM ANOVA) was performed for the overall experimental method. If the significance of the group factors was subsequently confirmed, one-way analysis of variance (one-way ANOVA) was implemented and post-validation was performed using the Tukey post hoc test. Differences associated with the application of Emdogain were verified using the paired $t$-test. Differences with values of $p<0.05$ were considered statistically significant.

\section{Results}

\subsection{Cell Viability Measurement}

There was no significant difference between the experimental groups, with or without Emdogain application, and the control group at day 1 (Figure $1 \mathrm{~A}, p>0.05$ ). Significantly more cell proliferation was observed only in the Endocem MTA Premixed group, with or without Emdogain application, compared with the other groups at day 2 (Figure 1B, $p<0.05)$. At days 1 and 2, all groups treated with Emdogain showed significantly higher cell proliferation compared with those without Emdogain (Figure 1A,B, $p<0.05$ ), whereas a significant difference between Emdogain-treated and untreated cells was observed only in the control group at day 4 (Figure $1 C, p<0.05$ ). 

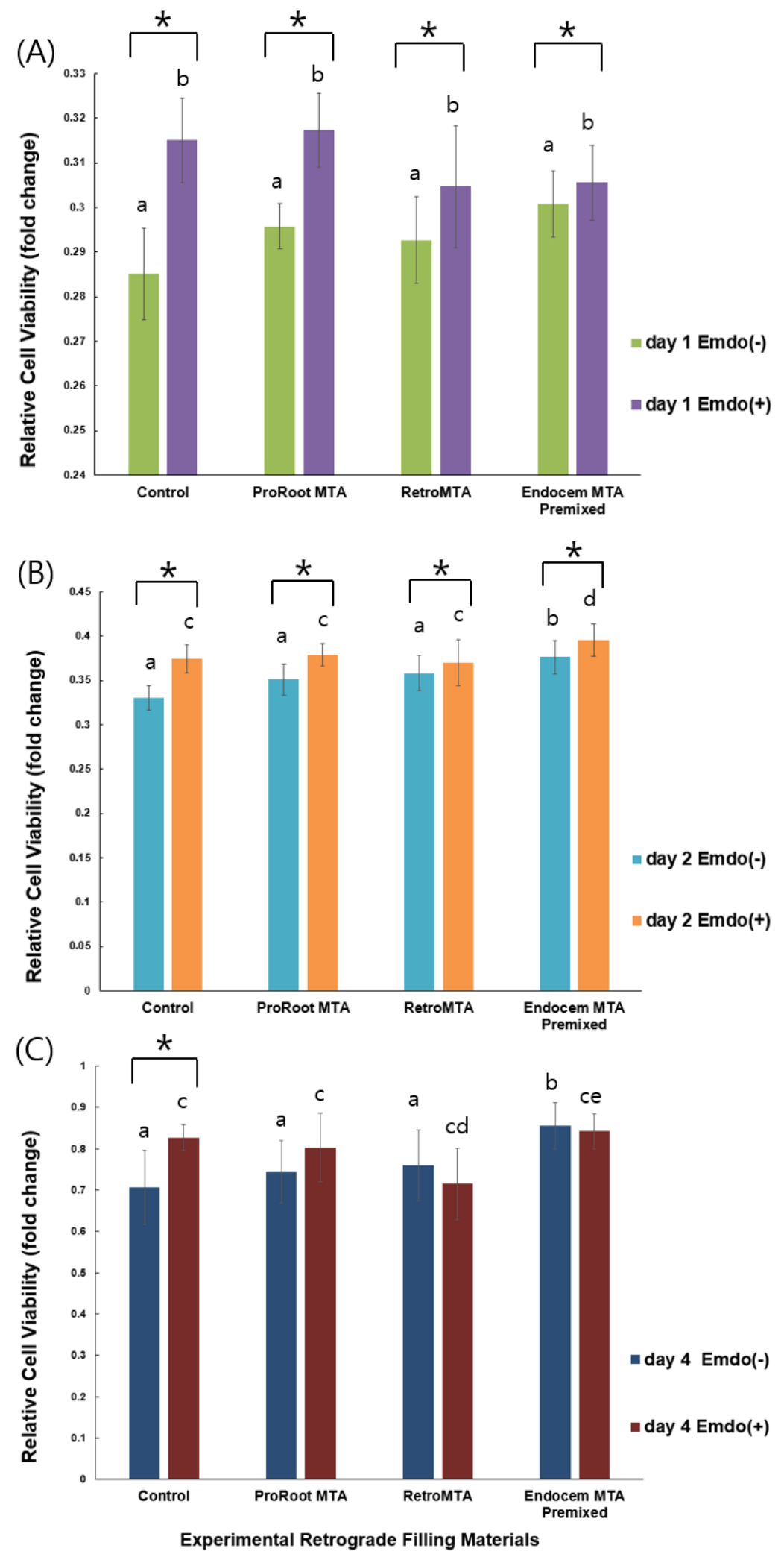

Figure 1. Comparison of cell viability values by material with or without Emdogain application at (A) day 1, (B) day 2, and (C) day 4. Different letters indicate statistically significant differences between the tested materials, and stars indicate that there are statistically significant differences between cells with and without Emdogain application. 


\subsection{Cell Migration Assay}

Regardless of Emdogain application, wound-healing values increased significantly over time, with no material-specific effects (Figure 2). The control and Endocem MTA Premixed groups with Emdogain presented significantly higher wound healing percentages at day 1 (Figure 2A, $p<0.05$ ), as did the control group alone at day 2 (Figure 2B, $p<0.05$ ). At day 4 , all groups showed almost complete wound healing. Representative images of each group are shown in Figure 3.

\subsection{Alkaline Phosphatase (ALP) Activity}

At days 3 and 6, there were no differences between the experimental groups without Emdogain application, and all the experimental groups showed higher ALP activity than that of the control group (Figure 4). At day 3, all groups with Emdogain application showed significantly higher ALP activity than those without Emdogain (Figure 4A, $p<0.05$ ), whereas only the control and ProRoot MTA groups did at day 6 (Figure 4B, $p<0.05)$.

\subsection{Alizarin Red-S (ARS) Staining Assay}

Overall, we observed increased ARS staining at day 14 compared with that at day 7 (Figure 5). There were no material-specific differences at day 7. However, all groups treated with Emdogain presented significantly higher ARS staining than those without Emdogain (Figure 5A, $p<0.05$ ). At day 14, especially when Emdogain was applied, the ARS staining of the RetroMTA and Endocem MTA Premixed groups was significantly higher than that of the ProRoot MTA and control groups (Figure 5B, $p<0.05$ ). Representative images of each group are shown in Figure 6. 

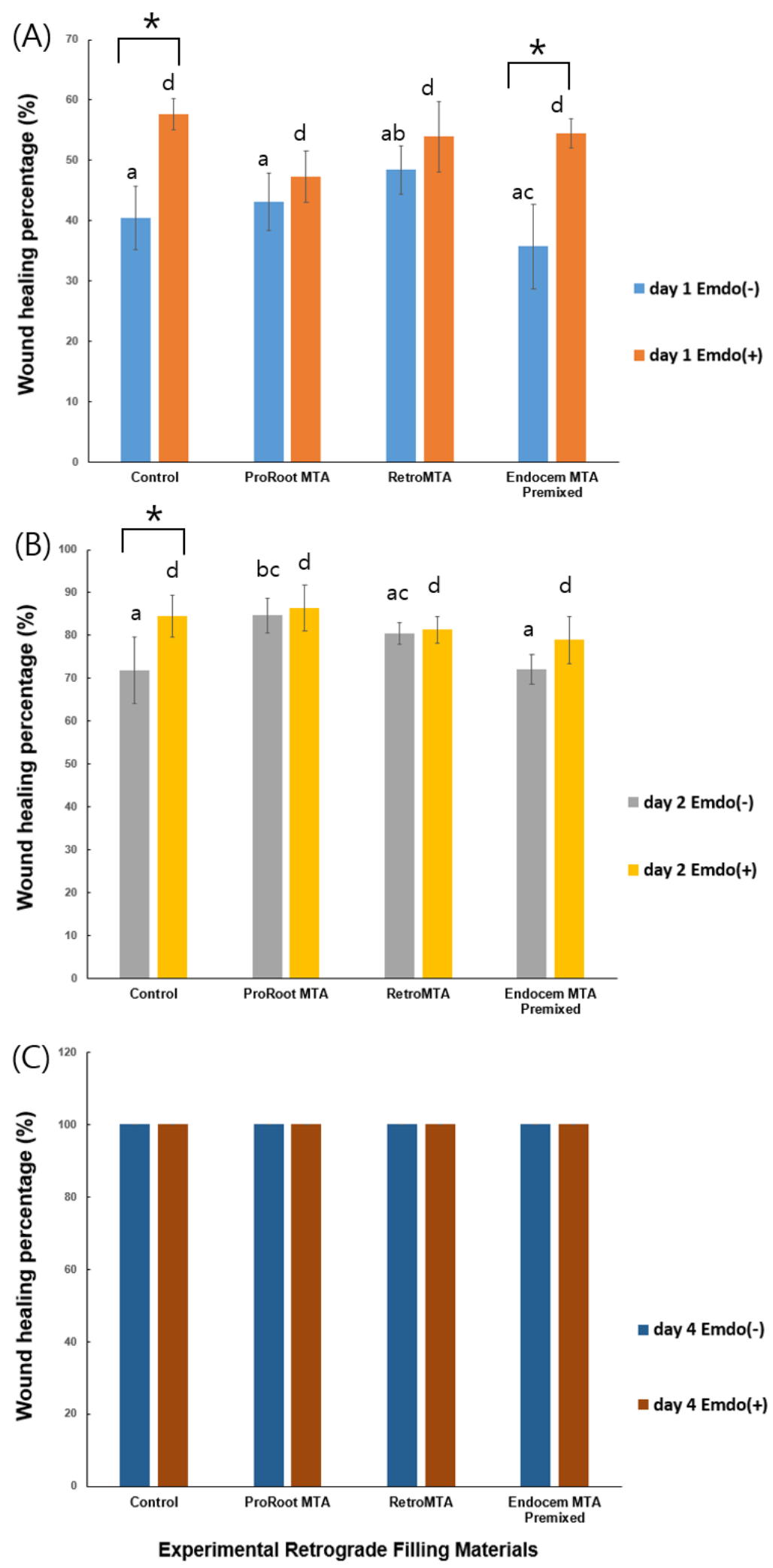

Figure 2. Comparison of cell migration values by material with or without Emdogain at (A) day 1, (B) day 2, and (C) day 4. Different letters indicate statistically significant differences between the tested materials, and stars indicate that there are statistically significant differences between cells with and without Emdogain application. 

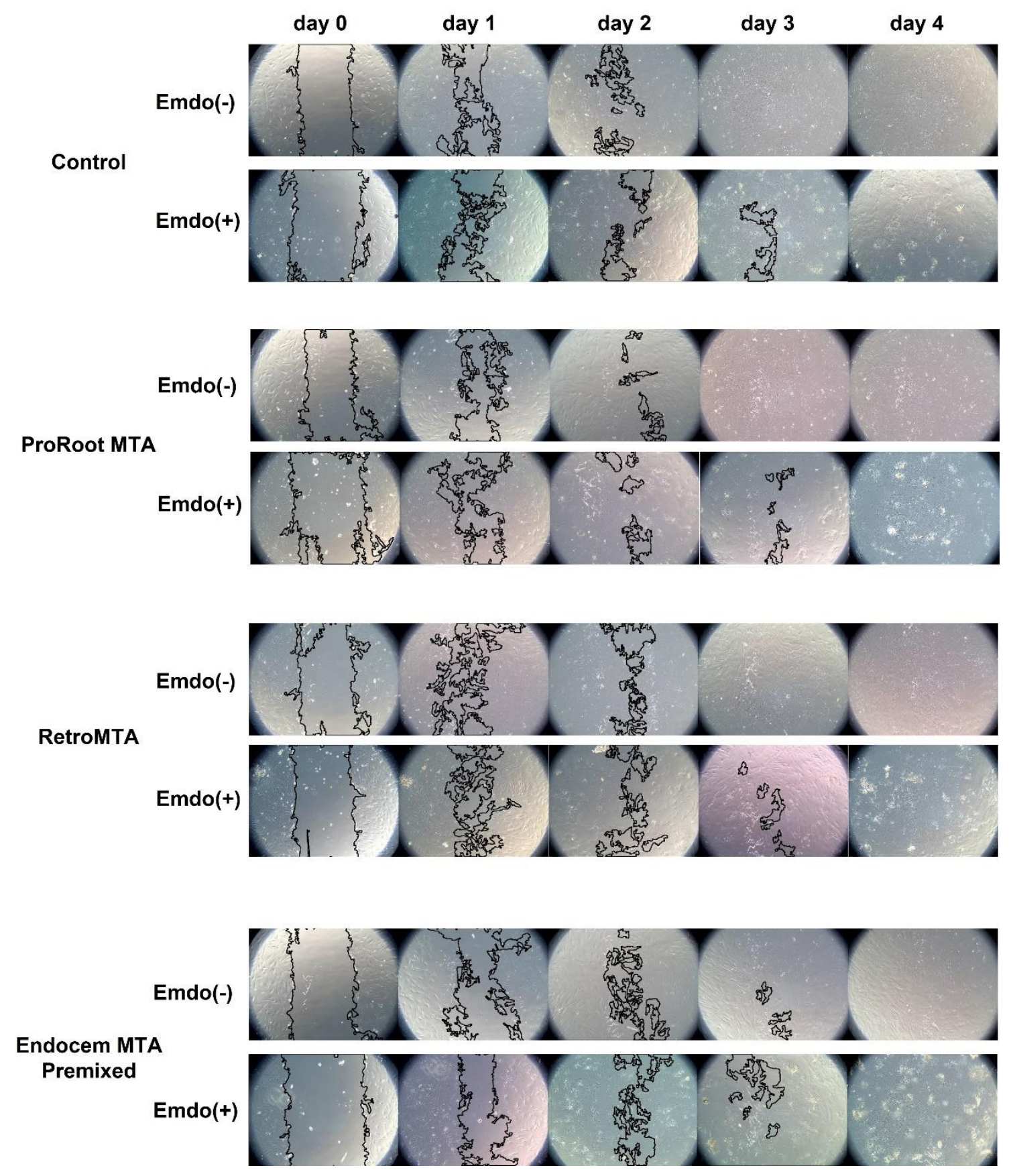

Figure 3. Representative images from the cell migration assay. 

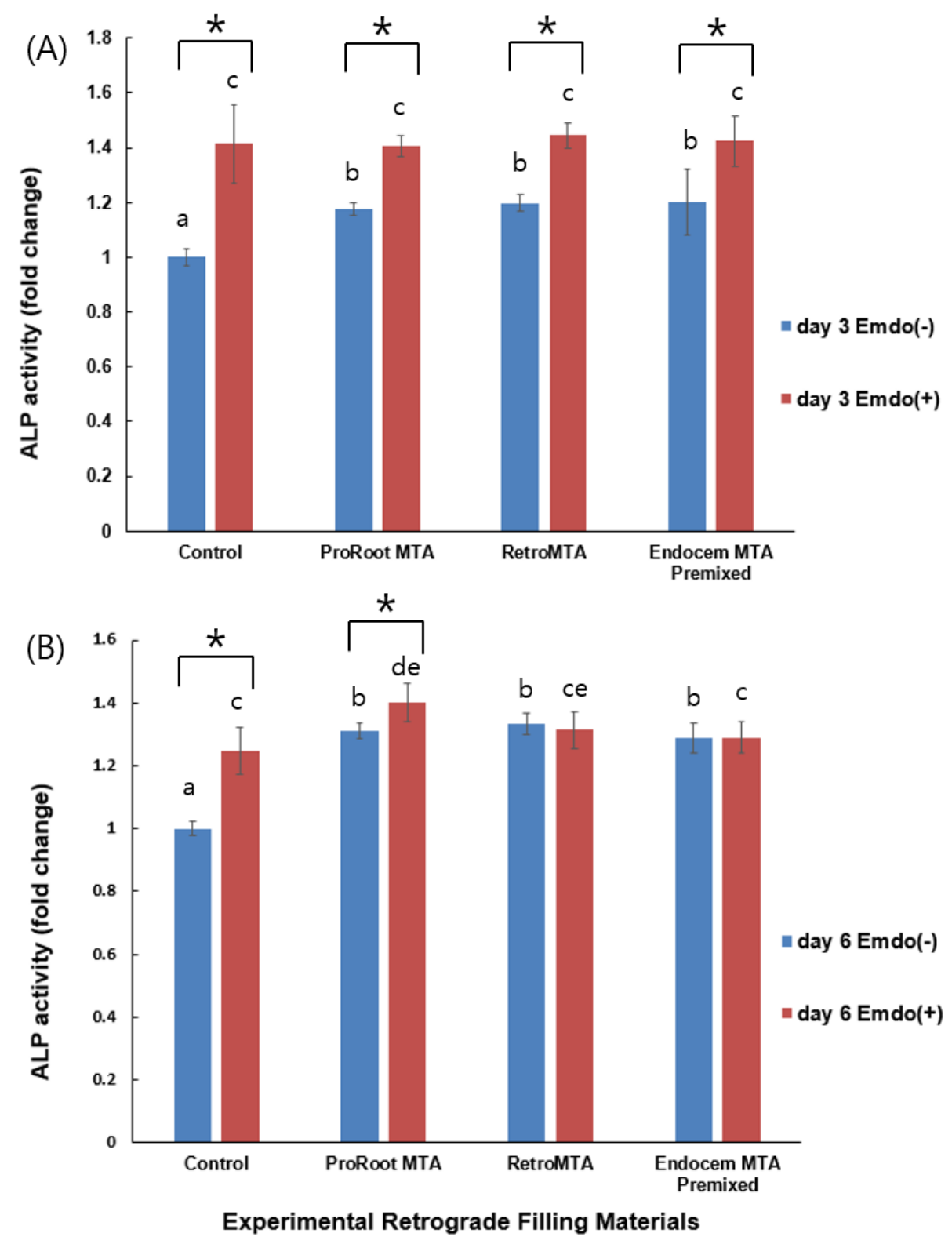

Figure 4. Comparison of ALP activity by tested material with or without Emdogain at (A) day 3, and (B) day 6. Different letters indicate statistically significant differences between the tested materials, and stars indicate that there are statistically significant differences between cells with and without Emdogain application. 

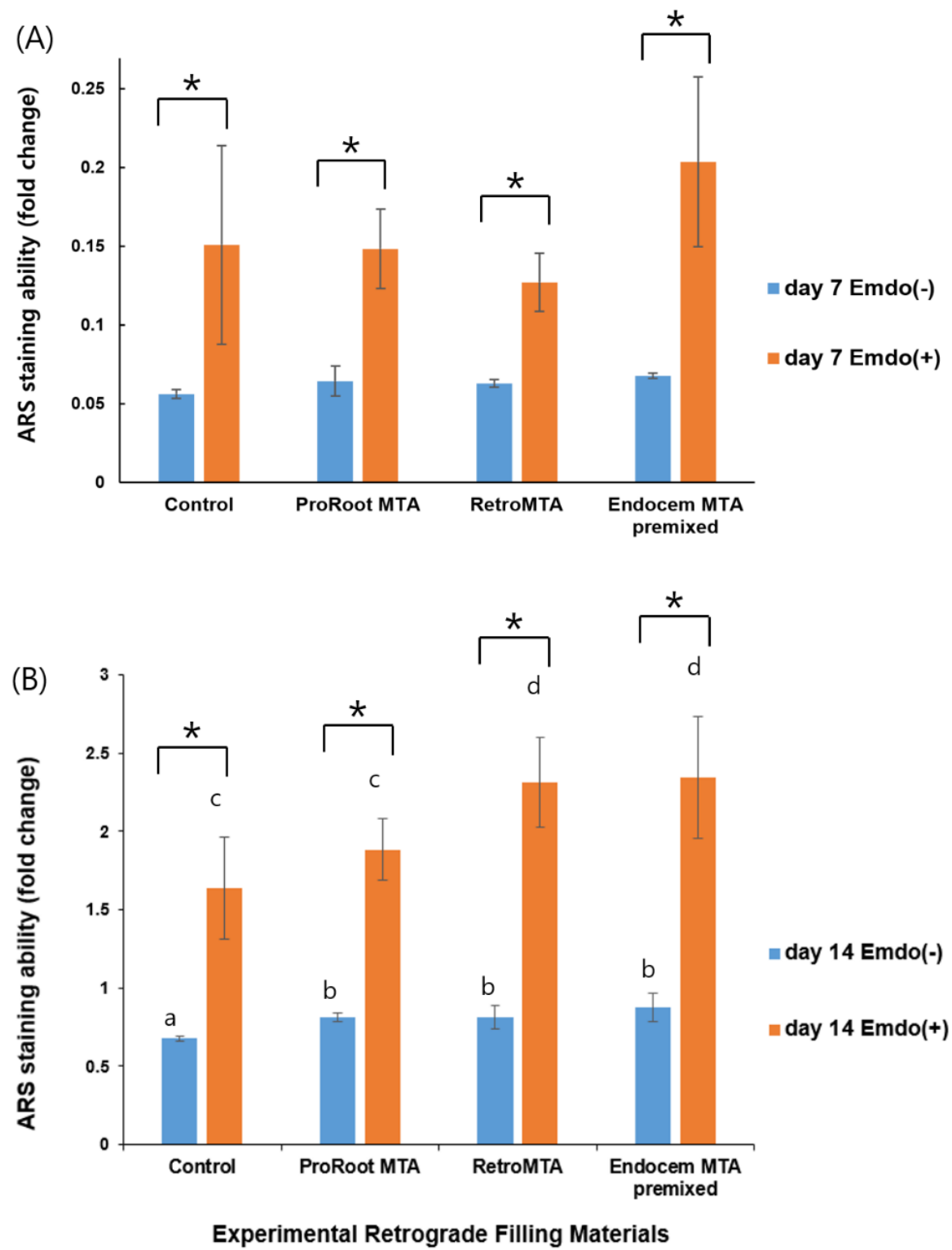

Figure 5. Comparison of ARS staining by material with or without Emdogain at (A) day 7, and (B) day 14. Different letters indicate statistically significant differences between tested materials, and stars indicate that there are statistically significant differences between cells with and without Emdogain application. 


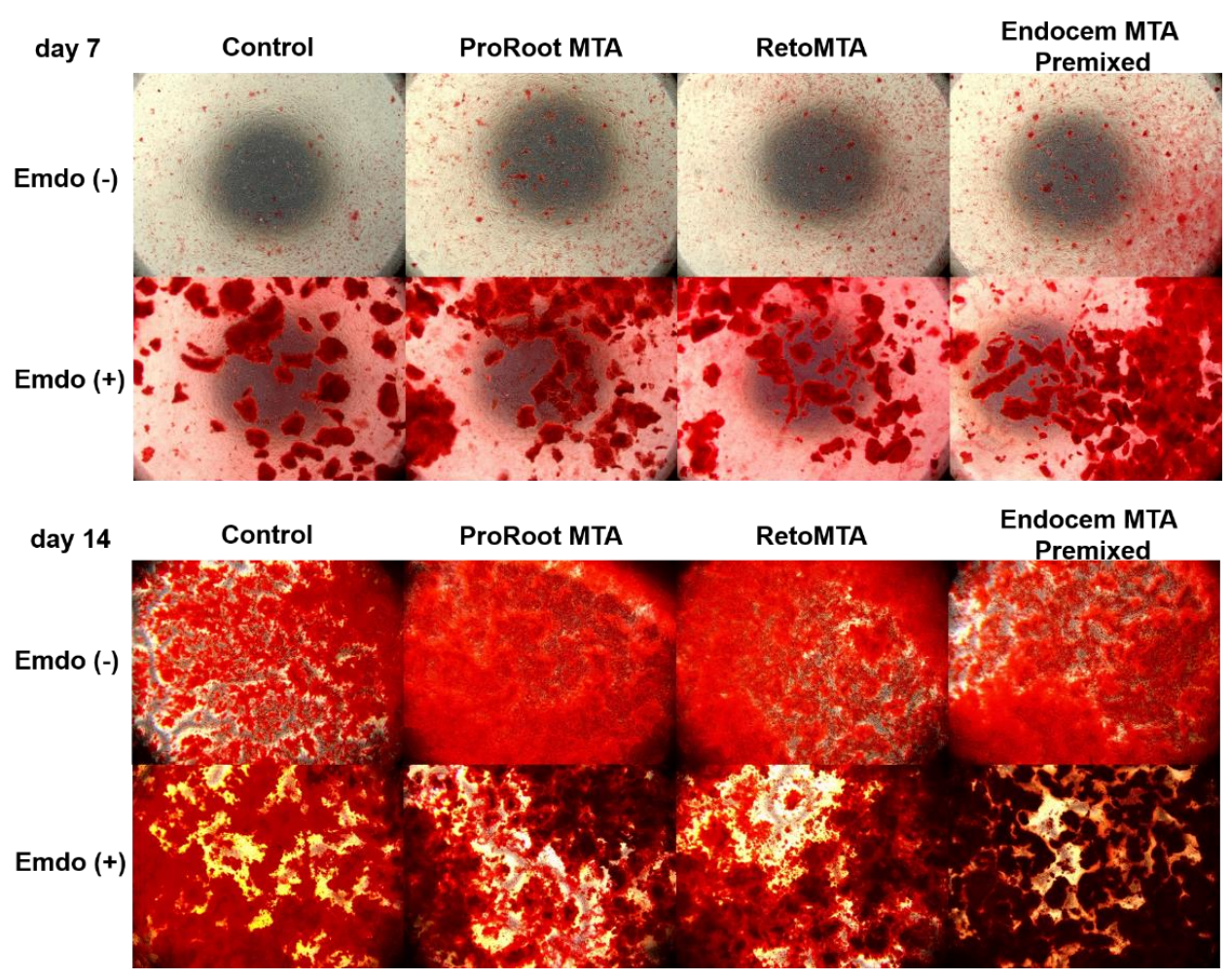

Figure 6. Representative images from the ARS staining assay.

\section{Discussion}

MTA was introduced to facilitate bone regeneration, due to its excellent biocompatibility and antibacterial and sealing ability in apical microsurgery [4]. However, because bleeding in the surgical field may inhibit the hardening of MTA, CSCs have been developed to overcome this problem [15-18]. In addition, the use of EMD to promote pulp stem cell proliferation and hard tissue regeneration in endodontic dentistry has recently been reported [26-30]. Conventionally, EMD was considered to be a material with great potential to enhance the regeneration of periodontal tissue [22-25]. In this study, we compared the biocompatibility and osteogenic potential of ProRoot MTA, RetroMTA, and Endocem MTA Premixed combined with Emdogain on hBMSCs.

We assayed CCK-8 analysis and a wound-healing assay to evaluate the biocompatibility of ProRoot MTA, RetroMTA, and Endocem MTA Premixed. Biocompatibility is the first essential factor in cell differentiation and the production of extracellular mineralized materials. The most commonly used cell viability assays are tetrazolium reduction, resazurin reduction, and the protease activity assay, all of which measure the general metabolism or enzymatic activity of viable cells [31]. Methyl thiazol tetrazolium (MTT) chromatic analysis has been widely used as a standard technique for assessing the cytotoxicity of biomaterials [32-34]. However, the MTT assay underestimates cell damage and can detect cell death only at the later stage of apoptosis when cell metabolism is significantly reduced [35]. To evaluate the cytotoxic effect of various CSCs on hBMSC, we used the CCK-8 method, which is known for its superior sensitivity and low cytotoxicity compared with the MTT assay and is also convenient for measuring the same sample repeatedly [36]. Cell migration to scratch sites is an important indicator of a material's biocompatibility [37].

In this study, biological responses showed that there was no significant difference between the ProRoot MTA, RetroMTA, Endocem MTA premixed, and control groups without Emdogain application. In other words, neither MTA nor CSCs had a detrimental effect on cell survival, but Endocem MTA Premixed provided significantly higher cell viability than the other treatments and the control at days 2 and 4 (Figure 1B,C, $p<0.05$ ). When Emdogain was added, significant differences were observed in the early stages of 
the experiment (days 1 and 2), but the effect was not meaningful later. Thus, ProRoot MTA and RetroMTA are similarly biocompatible with hBMSCs, and cells cultured with Endocem MTA Premixed proliferated more than those in the other groups at days 2 and 4 . The addition of Emdogain improved the biological responses in comparison with those achieved without Emdogain in all the experimental groups, but the differences decreased over time.

Previous studies have found that the cell viability achieved using RetroMTA is similar to or higher than that of a control group $[19,20]$. Other studies have also reported superior or similar biocompatibility of human dental pulp stem cells (hDPSCs) when treated with ProRoot MTA [38,39], consistent with our results. In a previous study that compared the dental pulp stem cell (DPSC) biocompatibilities of ProRoot MTA and Emdogain using an MTT assay [26], Emdogain showed the least cytotoxicity to DPSC, with 77\% cell viability, followed by ProRoot MTA with 53\%. Moreover, Wang et al., [30] found that EMD enhances the mineralization activity of DPSC by upregulating odontoblast or osteoblast induction markers. The results of these studies are also in accord with ours; therefore, EMD could be an alternative or adjuvant material to MTA. On the other hand, other studies have reported opposite results. In the study of Youssef et al., ProRoot MTA gave significantly lower cell viability compared with Emdogain [26]. In addition, a prior study by Bortoluzzi et al., [40] showed that eluates of MTA Angelus (Angelus Dental Solutions, Londrina, PR, Brazil) and Biodentine (Septodont, Saint Maur-des-Fosses, France) affect cell viability. The reason for this was not clear, but early release of calcium ions, ionic activity, toxic components, or $\mathrm{pH}$ changes might affect cells [41,42].

Osteogenic potential plays an important role in bone regeneration around teeth. In this study, we used ALP activity and an ARS staining assay to evaluate osteogenic potential. The ARS staining assay revealed significantly higher calcium nodule deposition at day 14 in the groups with MTA or CSCs than in the control group, and the effects of adding Emdogain were also greater. Regarding ALP activity, the groups with MTA or CSCs at days 3 and 6 had higher ALP levels than the control group. This demonstrates that MTA and CSCs increased the cells' osteogenic potential, and that the additional application of Emdogain would result in a higher degree of mineralization.

Santiago et al., reported a significant increase in ALP activity in a ProRoot MTA group compared with their control group. The bone sialoprotein (BNSP) gene, a marker of osteogenesis, was significantly overexpressed in the ProRoot group [43]. A study using hDPSCs exposed to ProRoot MTA indicated that high $\mathrm{pH}$ and the release of calcium ions can influence the differential expression of the osteogenesis markers BGLAP and BMP-2 [44]. Similarly, a previous study showed that the contact of ProRoot MTA and water produces calcium hydroxide, which leads to the release of calcium ions [20]. These studies all support our current finding that the use of ProRoot MTA with or without Emdogain resulted in higher ALP activity at days 3 and 6, and higher ARS staining at day 14. In the ALP analysis, the values in all groups treated with Emdogain were significantly higher only at day 3, whereas they were only higher in the control and ProRoot MTA groups at day 6. This means that in the groups treated with CSCs, such as RetroMTA and Endocem MTA Premixed, Emdogain can be thought to have an early effect on bone tissue formation at day 3. As the influence of Emdogain declined over time, CSC alone was sufficient to support osteogenic potential at day 6 .

When Emdogain was applied, calcium nodule deposition levels were significantly higher in all experimental groups and the control group, especially in the RetroMTA and Endocem MTA Premixed groups at day 14 (Figure 5B). Unlike the ALP activity results, the ARS results suggest that Emdogain continuously strengthened the bone tissue mineralization process during the 14 days of the experiment. In particular, components of the CSCs used in this study seemed to have more influence on hard tissue formation than ProRoot MTA, by continuously releasing calcium ions. The continuous release of calcium ions and silica components can affect bone formation [45,46]. Silica has been claimed to be an essential component of the CSC mechanism of action, inhibiting the formation of osteoclast 
and bone resorption [47]. For this reason, the ability to form calcium nodules continued to be higher in the CSC groups compared with the ProRoot MTA and control groups, until day 14. In this study, Emdogain also played an auxiliary role in the hBMSC mineralization process. Ishizaki et al., reported that odontoblasts and pulp cells are stimulated directly by Emdogain to produce collagen substrates for calcification [48]. Moreover, Guven et al., proved that EMD increases ALP activity and DSPP gene expression in comparison with ProRoot MTA [49]. The authors suggested that EMD increases hard tissue regeneration and can be used in pulp-capping procedures [49]. Other studies have also shown that Emdogain promotes bone and cementum production [50-53]. Kawase et al. suggested that amelogenin peptide or transforming growth factor- $\beta 1$ present in Emdogain is involved in cell signaling to stimulate substrate formation and mineralization [51,52].

The components from the material spread to the medium at different speeds, and this may indicate concentrations of the ingredients that have different effects. This may explain why the results of this in vitro study demonstrated differences between materials in their overall effectiveness on hBMSC. Therefore, in vivo research will be the next step to more accurately determine the ultimate impact of these substances and cells' reactions to them. Defining the clinical relevance of the findings is expected to require further research. However, despite these limitations, the results of this study justify using the various CSCs developed to overcome the disadvantages of MTA as retrograde filling materials during apical microsurgery. The additional application of Emdogain is expected to help with early cell proliferation and osteogenic potential, and therefore will increase the regeneration at the site of apical bone destruction.

Author Contributions: H.-M.K., D.L. and S.-Y.K. participated in the conceptualization in this study and evaluated the design of experimental methos. H.-M.K. and D.L. conducted all experimental procedures and acquired all the data. H.-M.K., D.L. and S.-Y.K. significantly contributed to the data analysis and results interpretation. H.-M.K., D.L. and S.-Y.K. were involved in the drafting, critical revising, and final editing of this manuscript. All authors have read and agreed to the published version of the manuscript.

Funding: This study was supported by a National Research Foundation of Korea (NRF) grant funded by the Ministry of Science, ICT, and Future Planning (NRF-2019R1F1A1058955) and Ministry of Education (NRF-2021R1I1A2041534).

Institutional Review Board Statement: The Institutional Review Board of Seoul St. Mary's Hospital, the Catholic University of Korea approved this study (IRB No. MC20SESI0067).

Informed Consent Statement: Not applicable.

Data Availability Statement: The datasets used and/or analyzed during the current study are available from the corresponding author on reasonable request.

Conflicts of Interest: There were no conflicts of interest related to this research. The funders had no role regarding the result of this study.

\section{References}

1. Kim, S.; Kratchman, S. Modern endodontic surgery concepts and practice: A review. J. Endod. 2006, 32, 601-623. [CrossRef]

2. Kang, S.; Ha, S.W.; Kim, U.; Kim, S.; Kim, E. A One-Year Radiographic Healing Assessment after Endodontic Microsurgery Using Cone-Beam Computed Tomographic Scans. J. Clin. Med. 2020, 9, 3714. [CrossRef]

3. Schloss, T.; Sonntag, D.; Kohli, M.R.; Setzer, F.C. A Comparison of 2- and 3-dimensional Healing Assessment after Endodontic Surgery Using Cone-beam Computed Tomographic Volumes or Periapical Radiographs. J. Endod. 2017, 43, 1072-1079. [CrossRef]

4. Parirokh, M.; Torabinejad, M. Mineral trioxide aggregate: A comprehensive literature review-Part I: Chemical, physical, and antibacterial properties. J. Endod. 2010, 36, 16-27. [CrossRef] [PubMed]

5. D'Antò, V.; Di Caprio, M.P.; Ametrano, G.; Simeone, M.; Rengo, S.; Spagnuolo, G. Effect of mineral trioxide aggregate on mesenchymal stem cells. J. Endod. 2010, 36, 1839-1843. [CrossRef] [PubMed]

6. Ber, B.S.; Hatton, J.F; Stewart, G.P. Chemical modification of proroot mta to improve handling characteristics and decrease setting time. J. Endod. 2007, 33, 1231-1234. [CrossRef]

7. Boutsioukis, C.; Noula, G.; Lambrianidis, T. Ex vivo study of the efficiency of two techniques for the removal of mineral trioxide aggregate used as a root canal filling material. J. Endod. 2008, 34, 1239-1242. [CrossRef] 
8. Chng, H.K.; Islam, I.; Yap, A.U.; Tong, Y.W.; Koh, E.T. Properties of a new root-end filling material. J. Endod. 2005, 31, 665-668. [CrossRef]

9. Cummings, G.; Torabinejad, M. RS 53 Mineral trioxide aggregate (MTA) as an isolating barrier for internal bleaching. J. Endod. 1995, 4, 228. [CrossRef]

10. Dominguez, M.S.; Witherspoon, D.E.; Gutmann, J.L.; Opperman, L.A. Histological and scanning electron microscopy assessment of various vital pulp-therapy materials. J. Endod. 2003, 29, 324-333. [CrossRef]

11. Torabinejad, M.; Hong, C.; McDonald, F.; Ford, T.P. Physical and chemical properties of a new root-end filling material. J. Endod. 1995, 21, 349-353. [CrossRef]

12. Chen, I.; Karabucak, B.; Wang, C.; Wang, H.G.; Koyama, E.; Kohli, M.R.; Nah, H.D.; Kim, S. Healing after root-end microsurgery by using mineral trioxide aggregate and a new calcium silicate-based bioceramic material as root-end filling materials in dogs. J. Endod. 2015, 41, 389-399. [CrossRef]

13. Tang, J.J.; Shen, Z.S.; Qin, W.; Lin, Z. A comparison of the sealing abilities between Biodentine and MTA as root-end filling materials and their effects on bone healing in dogs after periradicular surgery. J. Appl. Oral Sci. 2019, 27, e20180693. [CrossRef] [PubMed]

14. Sluyk, S.; Moon, P.; Hartwell, G. Evaluation of setting properties and retention characteristics of mineral trioxide aggregate when used as a furcation perforation repair material. J. Endod. 1998, 24, 768-771. [CrossRef]

15. Malkondu, Ö.; Karapinar Kazandă̆, M.; Kazazoğlu, E. A review on biodentine, a contemporary dentine replacement and repair material. Biomed. Res. Int. 2014, 2014, 160951. [CrossRef] [PubMed]

16. Wang, X.; Chang, J.; Hu, S. A study on the sealing ability and antibacterial activity of $\mathrm{Ca}_{3} \mathrm{SiO}_{5} / \mathrm{CaCl}_{2}$ composite cement for dental applications. Dent. Mater. J. 2012, 31, 617-622. [CrossRef] [PubMed]

17. Ma, J.; Shen, Y.; Stojicic, S.; Haapasalo, M. Biocompatibility of two novel root repair materials. J. Endod. 2011, 37, 793-798. [CrossRef]

18. Sarkar, N.K.; Caicedo, R.; Ritwik, P.; Moiseyeva, R.; Kawashima, I. Physicochemical basis of the biologic properties of mineral trioxide aggregate. J. Endod. 2005, 31, 97-100. [CrossRef]

19. Chung, C.J.; Kim, E.; Song, M.; Park, J.W.; Shin, S.J. Effects of two fast-setting calcium-silicate cements on cell viability and angiogenic factor release in human pulp-derived cells. Odontology 2016, 104, 143-151. [CrossRef]

20. Wongwatanasanti, N.; Jantarat, J.; Sritanaudomchai, H.; Hargreaves, K.M. Effect of Bioceramic Materials on Proliferation and Odontoblast Differentiation of Human Stem Cells from the Apical Papilla. J. Endod. 2018, 44, 1270-1275. [CrossRef]

21. MTA Mall. Available online: http:/ /www.mtamall.com/product/detail.html?product_no=181\&cate_no=24\&display_group=1 (accessed on 22 October 2021).

22. Chung, H.; Yang, W.; Kim, M.; Ko, H. Comparison of the effects of enamel matrix derivative and mineral trioxide aggregate on the mineralization potential of human cementum-derived cells. J. Dent. Sci. 2011, 6, 153-157. [CrossRef]

23. Matarasso, M.; Iorio-Siciliano, V.; Blasi, A.; Ramaglia, L.; Salvi, G.E.; Sculean, A. Enamel matrix derivative and bone grafts for periodontal regeneration of intrabony defects. A systematic review and meta-analysis. Clin. Oral Investig. 2015, 19, 1581-1593. [CrossRef] [PubMed]

24. Aimetti, M.; Ferrarotti, F.; Mariani, G.M.; Romano, F. A novel flapless approach versus minimally invasive surgery in periodontal regeneration with enamel matrix derivative proteins: A 24-month randomized controlled clinical trial. Clin. Oral Investig. 2017, 21, 327-337. [CrossRef] [PubMed]

25. Lossdörfer, S.; Sun, M.; Götz, W.; Dard, M.; Jäger, A. Enamel matrix derivative promotes human periodontal ligament cell differentiation and osteoprotegerin production in vitro. J. Dent. Res. 2007, 86, 980-985. [CrossRef] [PubMed]

26. Youssef, A.-R.; Emara, R.; Taher, M.M.; Al-Allaf, F.A.; Almalki, M.; Almasri, M.A.; Siddiqui, S.S. Effects of mineral trioxide aggregate, calcium hydroxide, biodentine and Emdogain on osteogenesis, Odontogenesis, angiogenesis and cell viability of dental pulp stem cells. BMC Oral Health 2019, 19, 1-9. [CrossRef]

27. Scarparo, R.K.; Dondoni, L.; Böttcher, D.E.; Grecca, F.S.; Figueiredo, J.A.; Batista, E.L., Jr. Apical periodontium response to enamel matrix derivative as an intracanal medication in rat immature teeth with pulp necrosis: Radiographic and histologic findings. $J$. Endod. 2012, 38, 449-453. [CrossRef] [PubMed]

28. Wang, H.H.; Sarmast, N.D.; Shadmehr, E.; Angelov, N.; Shabahang, S.; Torabinejad, M. Application of enamel matrix derivative (Emdogain) in endodontic therapy: A comprehensive literature review. J. Endod. 2018, 44, 1066-1079. [CrossRef]

29. Fransson, H.; Petersson, K.; Davies, J. Dentine sialoprotein and Collagen I expression after experimental pulp capping in humans using Emdogain ${ }^{\circledR}$ Gel. Int. Endod. J. 2011, 44, 259-267. [CrossRef]

30. Wang, Y.; Zhao, Y.; Ge, L. Effects of the enamel matrix derivative on the proliferation and odontogenic differentiation of human dental pulp cells. J. Dent. 2014, 42, 53-59. [CrossRef]

31. Riss, T.L.; Moravec, R.A.; Niles, A.L.; Duellman, S.; Benink, H.A.; Worzella, T.J.; Minor, L. Cell viability assays. In Assay Guidance Manual; Eli Lilly \& Company and the National Center for Advancing Translational Sciences: Bethesda, MD, USA, 2016. Available online: https: / / www.ncbi.nlm.nih.gov/books/NBK144065/ (accessed on 22 October 2021).

32. Gorduysus, M.; Avcu, N.; Gorduysus, O.; Pekel, A.; Baran, Y.; Avcu, F.; Ural, A.U. Cytotoxic effects of four different endodontic materials in human periodontal ligament fibroblasts. J. Endod. 2007, 33, 1450-1454. [CrossRef] [PubMed]

33. Jafarnia, B.; Jiang, J.; He, J.; Wang, Y.-H.; Safavi, K.E.; Zhu, Q. Evaluation of cytotoxicity of MTA employing various additives. Oral Surg. Oral Med. Oral Pathol. Oral Radiol. Endod. 2009, 107, 739-744. [CrossRef] [PubMed] 
34. Hirschman, W.R.; Wheater, M.A.; Bringas, J.S.; Hoen, M.M. Cytotoxicity comparison of three current direct pulp-capping agents with a new bioceramic root repair putty. J. Endod. 2012, 38, 385-388. [CrossRef]

35. Wei, W.; Qi, Y.-P.; Nikonov, S.Y.; Niu, L.-N.; Messer, R.L.; Mao, J.; Primus, C.M.; Pashley, D.H.; Tay, F.R. Effects of an experimental calcium aluminosilicate cement on the viability of murine odontoblast-like cells. J. Endod. 2012, 38, 936-942. [CrossRef] [PubMed]

36. Dojindo Molecular Technologies. Available online: https://dojindo.com/product/cell-counting-kit-8/ (accessed on 22 October 2021).

37. Luo, J.; Xu, J.; Cai, J.; Wang, L.; Sun, Q.; Yang, P. The in vitro and in vivo osteogenic capability of the extraction socket-derived early healing tissue. J. Periodontol. 2016, 87, 1057-1066. [CrossRef]

38. Kim, Y.; Lee, D.; Kim, H.-M.; Kye, M.; Kim, S.-Y. Biological Characteristics and Odontogenic Differentiation Effects of Calcium Silicate-Based Pulp Capping Materials. Materials 2021, 14, 4661. [CrossRef] [PubMed]

39. Kim, Y.; Lee, D.; Song, D.; Kim, H.-M.; Kim, S.-Y. Biocompatibility and bioactivity of set direct pulp capping materials on human dental pulp stem cells. Materials 2020, 13, 3925. [CrossRef]

40. Bortoluzzi, E.A.; Niu, L.-N.; Palani, C.D.; El-Awady, A.R.; Hammond, B.D.; Pei, D.-D.; Tian, F.-C.; Cutler, C.W.; Pashley, D.H.; Tay, F.R. Cytotoxicity and osteogenic potential of silicate calcium cements as potential protective materials for pulpal revascularization. Dent. Mater. 2015, 31, 1510-1522. [CrossRef]

41. Gandolfi, M.G.; Ciapetti, G.; Taddei, P.; Perut, F.; Tinti, A.; Cardoso, M.V.; Van Meerbeek, B.; Prati, C. Apatite formation on bioactive calcium-silicate cements for dentistry affects surface topography and human marrow stromal cells proliferation. Dent. Mater. 2010, 26, 974-992. [CrossRef]

42. Matsuya, S.; Takagi, S.; Chow, L.C. Effect of mixing ratio and $\mathrm{pH}$ on the reaction between $\mathrm{Ca}_{4}\left(\mathrm{PO}_{4}\right)_{2} \mathrm{O}$ and CaHPO 4 . J. Mater. Sci. Mater. Med. 2000, 11, 305-311. [CrossRef]

43. Santiago, M.C.; Gomes-Cornélio, A.L.; de Oliveira, L.A.; Tanomaru-Filho, M.; Salles, L.P. Calcium silicate-based cements cause environmental stiffness and show diverse potential to induce osteogenesis in human osteoblastic cells. Sci. Rep. 2021, 11, 1-11. [CrossRef]

44. Rathinam, E.; Govindarajan, S.; Rajasekharan, S.; Declercq, H.; Elewaut, D.; De Coster, P.; Martens, L.; Leybaert, L. The calcium dynamics of human dental pulp stem cells stimulated with tricalcium silicate-based cements determine their differentiation and mineralization outcome. Sci. Rep. 2021, 11, 1-13.

45. Mladenović, Ž.; Johansson, A.; Willman, B.; Shahabi, K.; Björn, E.; Ransjö, M. Soluble silica inhibits osteoclast formation and bone resorption in vitro. Acta Biomater. 2014, 10, 406-418. [CrossRef]

46. Gandolfi, M.G.; Siboni, F.; Botero, T.; Bossù, M.; Riccitiello, F.; Prati, C. Calcium silicate and calcium hydroxide materials for pulp capping: Biointeractivity, porosity, solubility and bioactivity of current formulations. J. Appl. Biomater. Funct. Mater. 2015, 13, 43-60. [CrossRef]

47. Yuan, W.; He, X.; Zhang, J.; Chen, Y.; Gong, T.; Zhu, Y. Calcium phosphate silicate and calcium silicate cements suppressing osteoclasts activity through cytokine regulation. J. Nanosc. Nanotechnol. 2018, 18, 6799-6804. [CrossRef]

48. Ishizaki, N.T.; Matsumoto, K.; Kimura, Y.; Wang, X.; Yamashita, A. Histopathological study of dental pulp tissue capped with enamel matrix derivative. J. Endod. 2003, 29, 176-179. [CrossRef]

49. Guven, E.P.; Yalvac, M.E.; Sahin, F.; Yazici, M.M.; Rizvanov, A.A.; Bayirli, G. Effect of dental materials calcium hydroxidecontaining cement, mineral trioxide aggregate, and enamel matrix derivative on proliferation and differentiation of human tooth germ stem cells. J. Endod. 2011, 37, 650-656. [CrossRef] [PubMed]

50. Boyan, B.D.; Weesner, T.; Lohmann, C.; Andreacchio, D.; Carnes, D.; Dean, D.; Cochran, D.; Schwartz, Z. Porcine fetal enamel matrix derivative enhances bone formation induced by demineralized freeze dried bone allograft in vivo. J. Periodontol. 2000, 71, 1278-1286. [CrossRef] [PubMed]

51. Kawase, T.; Okuda, K.; Momose, M.; Kato, Y.; Yoshie, H.; Burns, D.M. Enamel matrix derivative (EMDOGAIN $\left.{ }^{\circledR}\right)$ rapidly stimulates phosphorylation of the MAP kinase family and nuclear accumulation of smad2 in both oral epithelial and fibroblastic human cells. J. Periodontal Res. 2001, 36, 367-376. [CrossRef]

52. Kawase, T.; Okuda, K.; Yoshie, H.; Burns, D.M. Anti-TGF- $\beta$ antibody blocks enamel matrix derivative-induced upregulation of p21WAF1/cip1 and prevents its inhibition of human oral epithelial cell proliferation. J. Periodontal Res. 2002, 37, $255-262$. [CrossRef] [PubMed]

53. Kémoun, P.; Gronthos, S.; Snead, M.L.; Rue, J.; Courtois, B.; Vaysse, F.; Salles, J.-P.; Brunel, G. The role of cell surface markers and enamel matrix derivatives on human periodontal ligament mesenchymal progenitor responses in vitro. Biomaterials 2011, 32, 7375-7388. [CrossRef] 